\title{
Evaluation of TIG dental welding applied to Ti-6Al-4V alloys with different diameters: Analysis by Ultimate Tensile Strength, Vickers Hardness, and Finite
}

\section{Element Method}

\author{
Avaliação da soldagem TIG em liga de Ti-6Al-4V com diferentes diâmetros: Análise por resistência \\ à tração, dureza Vickers e método de elementos finitos \\ Evaluación de soldadura TIG en aleación Ti-6Al-4V con diferentes diámetros: Análisis por \\ resistencia a tracción, dureza Vickers y método de elementos finitos
}

Received: 05/25/2021 | Reviewed: 05/31/2021 | Accept: 07/19/2021 | Published: 07/23/2021

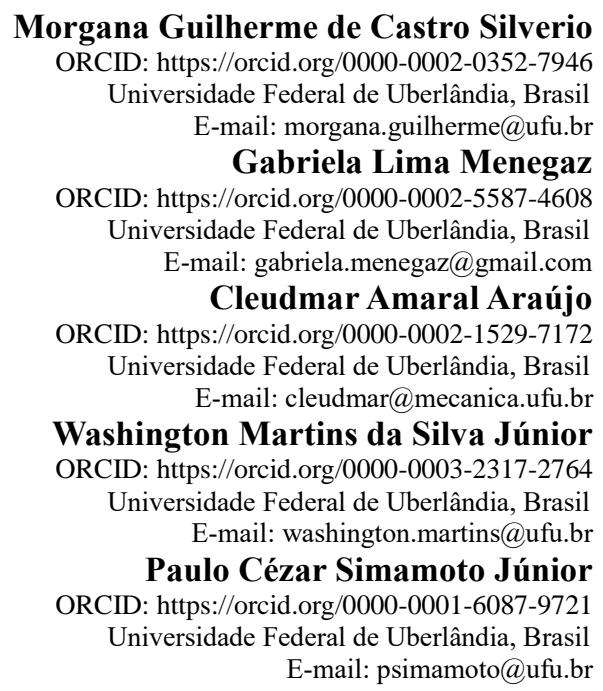

\begin{abstract}
There is limited information in literature regarding the accomplishment of Ti-6Al-4V TIG joints welded in prefabricated bars applied to dentistry. Evaluate the ultimate tensile strength and Vickers hardness of Ti-6Al-4V alloy subjected to TIG (Tungsten Inert Gas) welding technique in different diameters. Material and methods: Forty-five specimens were prepared and divided into 5 groups: control group $(\mathrm{CG})(\mathrm{n}=5)$, with intact bars in a diameter of 3.0mm, and groups TIG2.5, TIG3, TIG4, TIG5 ( $\mathrm{n}=10)$ with diameters of 2.5, 3, 4 and $5 \mathrm{~mm}$ respectively, welded with TIG in a pulse of $10(\mathrm{~ms})$ and in a depth of $3(\mathrm{~A})$. The specimens were tested by both radiographic inspection and penetrating liquids. After that, they were tested by ultimate tensile strength (UTS) and the elongation percentage (EP) was obtained. Images from fractured samples were taken and the welded areas percentage (WAP) was calculated. Random images were also taken by scanning electron microscope (SEM). Vickers hardness was obtained for base metal (BM), Heat affected zone (HAZ) and Welded zone (WZ). Finite element models were constructed. One-way Anova, Dunnet and Tukey tests $(\alpha=.05)$ were used for statistical analysis of UTS, WAP and EP for different groups and for differences in regions (BM, HAZ and WZ). Finite element models were developed in a workbench environment with boundary conditions simulating a tensile test. The majority of the specimens showed internal voids on radiographic inspection, but porosities or groves were not observed on their surface on penetrant liquid test. Most of the samples fractured in the welded area. The 1way ANOVA showed significant differences among the groups for UTS, WAP and EP values $(\mathrm{P}<.001)$. The Dunnett test showed that TIG3, TIG4 and TIG5 groups had lower UTS values than those of the CG, but TIG2.5 group had no statistical difference in relation to CG. The 1-way ANOVA showed significant differences among the regions $(\mathrm{P}<.001)$ for Vickers hardness. Under the experimental conditions described, the diameter of 2.5 seems to be the best option for joining prefabricated rods in this kind of union and in this regulation of the machine.
\end{abstract}

Keywords: Dental soldering; Scanning electron microscopy; Finite element analysis. 


\begin{abstract}
Resumo
Avaliou-se neste trabalho a resistência à tração e a dureza Vickers da liga de Ti-6Al-4V submetida à soldagem TIG (Tungsten Inert Gas) em diferentes diâmetros. Quarenta e cinco amostras foram divididas em 5 grupos: grupo controle (CG) $(\mathrm{n}=5)$, com barras intactas e grupos TIG2.5, TIG3, TIG4, TIG5 ( $\mathrm{n}=10)$ com diâmetros de $2.5,3,4$ e 5 mm respectivamente, soldadas com $10(\mathrm{~ms})$ e 3 (A) e juntas em I. Foram aplicados os teste de inspeção radiográfica e líquidos penetrantes e em seguida o teste de tração (UTS) e obtenção da porcentagem de alongamento (EP). Após a fratura, a porcentagem de área soldada (WAP) foi calculada. Imagens aleatórias foram analisadas em microscópio eletrônico de varredura. A dureza Vickers foi executada no metal base (BM), zona afetada calor (HAZ) e zona da solda (WZ). Modelos de elementos finitos semelhantes aos modelos experimentais foram construídos com condições de contorno simulando um teste de tração. Foram aplicados os testes Anova one-way, Dunnett e Tukey $(\alpha=0,05)$ para a análise estatística. Anova one-way mostrou diferenças significativas entre os grupos para valores de UTS, WAP e EP $(\mathrm{P}<.001)$. O teste de Dunnett mostrou que os grupos TIG3, TIG4 e TIG5 apresentaram valores de UTS menores que os do GC, mas o grupo TIG2.5 não apresentou diferença estatística em relação ao GC. Anova one-way mostrou diferenças significativas entre as regiões $(\mathrm{P}<.001)$ para a dureza Vickers. Sob as condições experimentais descritas, o diâmetro de 2.5 parece ser a melhor opção para unir barras pré-fabricadas neste tipo de junta e nesta regulagem da máquina.
\end{abstract}

Palavras chave: Soldagemdentária; Microscopia eletrônica de varredura; Método de elementos finitos.

\title{
Resumen
}

En este trabajo se evaluó la resistencia a la tracción y dureza Vickers de la aleación Ti-6Al-4V sometida a soldadura TIG (Tungsten Inert Gas) en diferentes diámetros. Se dividieron 45 muestras en 5 grupos: grupo control $(\mathrm{CG})(\mathrm{n}=5)$, con barras intactas y grupos TIG2.5, TIG3, TIG4, TIG5 $(\mathrm{n}=10)$ con diámetros de 2.5, 3, 4 y 5 mm respectivamente, soldadas con 10 (ms) y 3 (A) y juntas I. Se aplicaron las pruebas de inspección radiográfica y líquidos penetrantes, seguidas de la prueba de tracción (UTS) y porcentaje de elongación (EP). Después de la fractura, se calculó el porcentaje de área soldada (WAP). Las imágenes aleatorias se analizaron utilizando un microscopio electrónico de barrido. La dureza de Vicker se realizó en el metal base (BM), la zona afectada por el calor (HAZ) y la zona de soldadura (WZ). Se construyeron modelos de elementos finitos similares a los modelos experimentales con condiciones de contorno que simulan una prueba de tracción. Para el análisis estadístico se aplicaron las pruebas Anova unidireccional, Dunnett y Tukey $(\alpha=0,05)$. El ANOVA de una vía mostró diferencias significativas entre los grupos para los valores de UTS, WAP y EP ( $p<0,001)$. La prueba de Dunnett mostró que los grupos TIG3, TIG4 y TIG5 tenían valores de UTS más bajos que los del GC, pero el grupo TIG2.5 no mostró diferencia estadística en relación al GC. Anova unidireccional mostró diferencias significativas entre regiones $(\mathrm{P}<.001)$ para la dureza de Vicker. En las condiciones experimentales descritas, el diámetro de 2,5 parece ser la mejor opción para unir barras prefabricadas en este tipo de junta y en este ajuste de la máquina.

Palabras clave: Soldadura dental; Microscopía electrónica de barrido; Método de elementos finitos.

\section{Introduction}

The rehabilitation of edentulous jaws through prostheses fixed on implants of the ad modum Brånemark Protocol type has been well-documented, with high success rates (Lyra \& Silva, et al. 2012; Castro, et al. 2015; Silverio, et al. 2021). The focus of this study was on establishing this type of rehabilitation more quickly and more cost-effectively, for both professionals and patients (Lyra \& Silva, et al. 2012; Silveira-Júnior, et al. 2012; Castro, et al. 2015; Simamoto-Júnior, et al. 2015; Silverio, et al, 2021). Several investigators have studied implants, and others have assessed the metallic structures (Lyra \& Silva, et al. 2012; Silveira-Júnior, et al. 2012; Castro, et al. 2015; Simamoto-Júnior, et al. 2015; Silverio, et al. 2021).

The studies related to frameworks have focused on: welding technique types (Wang and Welsch, 1995; Baba \& Watanabe, 2005; Rocha, et al. 2006; Barbi, et al. 2012; Lyra e Silva, et al. 2012; Nuñez-Pantoja, et al. 2012; Atoui, et al. 2013; Castro, et al. 2013; Takayama, et al. 2013; Castro, et al. 2015; Simamoto-Júnior, et al. 2015, Perveen, et al. 2018); the settings of welding equipment (Chai \& Chou, 1998; Baba \& Watanabe, 2005; Akman, et al. 2009; Lyra \& Silva, et al. 2012; Silverio, et al. 2021); the types of alloys used (Lyra \& Silva, et al. 2012; Rocha, et al. 2006; Watanabe \& Topham, 2006; Takayama, et al. 2012; Takayama, et al. 2013; Perveen, et al. 2018); the configuration of the joints (Simamoto-Júnior, et al. 2015; Nuñez-Pantoja, et al. 2012; Takayama, et al. 2012; Kokolis, et al. 2015); and mechanical methods of evaluation of these welded joints (NuñezPantoja, et al. 2011; Takayama, et al. 2012; Castro, et al. 2015; Silverio, et al. 2021).

Among the possible approaches to creation of the framework, the most used technique is one in which parts of the bar are waxed, cast, and welded by means of brazing (Silveira-Júnior, et al. 2012; Berg, et al. 1995; Wang \& Welsch, 1995; Byrne, 
2011; Takayama, et al. 2013; Perveen, et al. 2018). Although it has been used for many years, this is a technique that requires a longer working time, has a higher cost of materials, and is not effective in joining titanium or its alloys (Lyra e Silva, et a. 2012; Silveira-Júnior, et al. 2012). More precise and simpler techniques can be used to achieve these goals. Thus, besides the use of prefabricated bars (Lyra \& Silva, et al. 2012, Castro, et al. 2015; Simamoto-Júnior, et al. 2015; Silverio, et al. 2021),which need not be cast, different types of welding — such as laser (Berg, et al. 1995; Wang \& Welsch, 1995; Chai \& Chou, 1998; Baba \& Watanabe, 2005; Akman, et al. 2009; Byrne, 2011; Nuñez-Pantoja, et al. 2011; Barbi, et al. 2012; Nuñez-Pantoja, et al. 2012; Silveira-Júnior, et al. 2012; Takayma, et al. 2012; Atoui, et al. 2013; Castro, et al. 2013; Takayama, et al. 2013; Castro, et al. 2015; Kokolis, et al. 2015; Perveen, et al. 2018) and arc welding, TIG (Tungsten Inert Gas) or plasma (Wang \& Welsch, 1995; Taylor, et al. 1998; Rocha, et al. 2006; Byrne, 2011; Barbi, et al. 2012; Lyra \& Silva, et al. 2012; Nuñez-Pantoja, et al. 2012; Silveira-Júnior, et al. 2012; Atoui, et al. 2013; Castro, et al. 2013; Castro, et al. 2015; Simamoto-Júnior, et al. 2015; Silverio, et al. 2021) have been studied over the past 40 years.

TIG welding is a technique whereby the highly localized heating of metal is done by means of a plasma arc established between the non-consumable electrode and the workpiece to be welded, leading to melting of the base metal (Wang \& Welsch, 1995; Taylor, et al. 1998; Rocha, et al. 2006; Byrne, 2011; Barbi, et al. 2012; Silveira-Júnior, et al. 2012; Castro, et al. 2015; Simamoto-Júnior, et al. 2015), generating welded joints with good quality and finish (Silveira-Júnior, et al. 2012; Castro, et al. 2015).Furthermore, this technique allows for the welding of many alloys, including titanium alloys, since the welding is done with protective gas such as helium and argon or a mixture thereof (Wang \& Welsch, 1995; Taylor, et al. 1998; Rocha, et al. 2006; Byrne, 2011; Barbi, et al. 2012; Nuñez-Pantoja, et al. 2012; Silveira-Júnior, et al. 2012; Atoui, et al. 2013; Castro, et al. 2013; Castro, et al. 2015; Simamoto-Júnior, et al. 2015).

In this scenario, titanium alloys are the most used for study, including studies targeted at prosthetic frameworks, because they have the advantages of good compatibility, low density, and anti-corrosion properties (Berg, et al. 1995; Chai \& Chou, 1998; Taylor, et al. 1998; Rocha, et al. 2006; Akman, et al. 2009; Lyra e Silva, et al. 2012; Nuñez-Pantoja, et al. 2011; NuñezPantoja, et al. 2012; Silveira-Júnior, et al. 2012; Takayama, et al. 2012; Atoui, et al. 2013; Castro, et al. 2015; Simamoto-Júnior, et al. 2015). However, there is great difficulty in casting and welding these alloys because, with high temperatures, they show high reactivity with oxygen, nitrogen and hydrogen, causing them to become contaminated and leaving the welded regions of the framework more vulnerable (Berg, et al. 1995; Wang \& Welsch, 1995; Chai \& Chou, 1998; Taylor, et al. 1998; Watanabe \& Topham, 2006; Akman, 2009; Nuñez-Pantoja, et al. 2011; Lyra e Silva, et al. 2012; Silveira-Júnior, et al. 2012; Nuñez-Pantoja, et al. 2012; Takayama, et al. 2012; Atoui, et al. 2013; Castro, et al. 2015; Simamoto-Júnior, et al. 2015). Thus, the TIG welding technique is well-suited for titanium and its alloys.

Regarding the method of evaluation, much research has been directed to the application of nondestructive methods such as evaluation by liquid penetrant (Simamoto-Júnior, et al. 2015),radiographic inspection (Rocha, et al. 2006; Lyra \& Silva, et al. 2012; Nuñez-Pantoja, et al. 2012; Silveira-Júnior, et al. 2012;Castro, et al. 2015; Simamoto-Júnior, et al. 2015), micro-CT (Takayama, et al. 2012; Silverio, et al. 2021), and finite element modeling — added to the destructive tests (Castro, et al. 2015) for a better understanding of these regions.

The purpose of this study was to evaluate the mechanical behavior of the Ti-6Al-4V alloy with different diameters subjected to the TIG welding technique by application of the ultimate tensile strength (UTS) test, Vickers Hardness test, and the Finite Element Method (FEM). The hypotheses tested were that: (1) there would be no difference between the control and welded groups in terms of UTS and Elongation Percentage (EP); (2) increasing the diameters would not influence the parameters (UTS, welded area percentage [WAP], and EP); and (3) there would be a difference in hardness values for the different regions - Base Metal (BM), Heat-affected Zone (HAZ), and Welded Zone (WZ). 


\section{Material and Methods}

\section{Ultimate Tensile Strength (UTS), Elongation Percentage (EP), and Welded Area Percentage (WAP)}

Forty-five dumbbell-shaped rods were machined from Ti-6Al-4V alloy (Realum; Indústria e Comércio de Metais Puros e Ligas Ltda) based on the ASTM E 8 norm (American Society for Testing Materials, 2008) with 2.5, 3.0, 4.0, and 5.0 mm diameters in the central segment and 84-mm length with $35 \mathrm{~mm}$ useful length. The specimen size was obtained from a calculation in the SigmaPlot program, with a .95 power of analysis. The specimens were machined into halves to be welded later in the TIG machine (NTY 60C; Kernit) ( $\mathrm{n}=10)$; those belonging to the control group $(\mathrm{CG})$ were machined intact $(\mathrm{n}=5)$. The specimens were divided into 5 groups: CG, TIG2.5, TIG3, TIG4, and TIG5.

The specimen halves were aligned in the metal matrix so that the parts to be welded were in complete abutment, to allow for standardization of the welding position for all groups.The TIG machine was adjusted for working with a 60 A depth (current density) and $120 \mathrm{~ms}$ pulse (continuous arc), and the welding was performed by the same operator (M.B. Santos) at one sitting. For this technique, 2 opposite welding points were marked to stabilize the specimens. The framework was then removed from the matrix to facilitate the welding of the entire circumference (Castro, et al. 2015).

After the welding procedures, the welded regions were evaluated radiographically (Timex 70; Gnatus) by digital imaging (X-Scan Duo; Air Techniques) for the detection of any defects, represented by radiolucent points at the joints (NuñezPantoja, et al. 2011; Nuñez-Pantoja, et al. 2012; Lyra e Silva, et al. 2012; Simamoto-Júnior, et al. 2015). Additionally, a dyerevealing liquid (VP 30; Metal- Chek) was applied for the detection of any surface failure (Simamoto-Júnior, et al. 2015).

The UTS measurement was carried out in a universal testing machine (MTS 810; Material Test System Corp) at a crosshead speed of $.02 \mathrm{~mm} / \mathrm{min}$ and $2500 \mathrm{Kgf}$ load cell. The UTS (MPa) was recorded when the specimens fractured, and the EP was obtained by subtraction of the final length from the initial length, with the result divided by the initial length. The initial length was obtained after welding was completed and was measured with a digital caliper. The final length was measured by positioning of the correct halves of the specimens fractured after UTS testing in the metal matrix so that fractures remained juxtaposed; this was also measured with a digital caliper. Percentages were obtained when the differences were multiplied by 100 (Castro, et al. 2015).

After the UTS test, both parts of the fractured specimens were subjected to evaluation of welding penetration in the fractured region through photographs taken by a digital camera, with the distance standardized and calibrated with macro increase and automatic function standardized and calibrated with the welded areas. The captured images were analyzed with Motic Images Plus 2.0 software for Windows (Motic; Richmond). All areas $\left(\mathrm{mm}^{2}\right)$ were measured and tabulated. The average for each specimen and then the average for all specimens were calculated. The values obtained were converted to percentages so that the different diameters could be compared (Castro, et al. 2015).

\section{Scanning Electron Microscopy (SEM)}

Since the specimens in each group had similar fracture patterns, 3 specimens of each diameter were subjected to SEM at $\times 20, \times 100, \times 500$, and $\times 1000$ magnification, and those images that were most representative were used to demonstrate the welded penetration area and the failure characteristics (JSM 5600LV; JEOL) (Castro, et al. 2015).

\section{Vickers Hardness}

Samples were subjected to the Vickers hardness test at a microhardness equipment (Shimadzu), according to ASTM E92 (American Society for Testing Materials, 2003) for measurement of hardness in different sections of the specimen - BM, HAZ, and WZ. Ten pyramidal impressions were obtained in each section of the test piece for subsequent statistical analysis. 


\section{Finite Element Analysis (FEM)}

Three-dimensional FE models based on the original $3.0 \mathrm{~mm}$ specimens used in the experimental analysis (UTS) were constructed by computer-aided design (CAD) software (Solidworks; Dassault Systems) for both intact and welded specimens (Castro, et al. 2015). The welded specimens were divided into 5 different parts: the region of the dumbbell, the region of the useful length without the weld region, the welded zone, the heat-affected zone, and the region of internal void. All parts were considered completely joined except the region of the internal void. The models of intact and welded specimens were then transferred to FE processing software (Abaqus 6.12; Dessault Systèmes).

To ensure consistency and accuracy in the simulations for this study, all FE models had a mesh with quadratic tetrahedral elements of C3D10 type, with high element density in the welded region of the specimen. The 3D models contained a total of 15229 elements and 23812 nodes for nonwelded specimens and 22369 elements and 36014 nodes for welded specimens.

All materials were assumed to behave with linear elasticity. The mechanical properties of the base material were 113.8 GPa and 0.342 for Young's modulus and Poisson's ratio, respectively (Welsch, et al. 1993). The Young's modulus increased an estimated 20\% for the $\mathrm{WZ}$ and $10 \%$ for the HAZ, because hardness increased at these percentages in these regions, based on the values of the Vickers test. Boundary conditions were defined in constraints on displacement and rotation in all direction of both sides of the specimens, allowing movement only in the $\mathrm{X}$ axis. The loading configuration followed that of the UTS analysis, with its direction parallel to the $\mathrm{X}$ axis. The load values used were obtained from the UTS test. After the processing step, data were obtained on displacement on the $\mathrm{X}$ axis $(\mathrm{mm})$ and on maximum principal stress $(\mathrm{MPa})$, and stress $\mathrm{x}$ strain curve were plotted.

Model validation was performed for the intact specimen. The values of the load applied in the UTS intact specimens were used as a reference for computer simulation. Strain and stress values of the numerical models were then compared with the results of the experimental group. Stress x strain curves were close, so the FE model was validated (Castro, et al. 2015).

\section{Statistical Analysis}

In the initial analysis, the goal was to determine the influence of one factor involved in this study: diameter. Therefore, the data were analyzed with 1-way ANOVA, and the Dunnett test was used to evaluate the differences in UTS and EP of the control and the 4 experimental groups. The Tukey test was also used to compare test groups in all parameters analyzed: UTS, EP, and WAP. The UTS and EP values were transformed into square root. After this, the Pearson correlation test was performed to correlate UTS with WAP.

The data were also analyzed with 1-way ANOVA to evaluate the differences in the factor 'Vickers hardness' in different regions of the specimen (BM, HAZ, and WZ). The Tukey test was also used to compare the regional values. For all tests, groups were considered statistically different at $\alpha=.05$.

The data found in the FE analysis were analyzed by direct comparative models generated for welding processes in relation to the model generated for the intact specimen and between the experimental and numerical models. At this time, in the FEM, the term 'experimental' was used to designate specimens that were subjected to the UTS test, whether or not they were welded (Castro, et al. 2015).

\section{Results}

Ultimate Tensile Strength (UTS), Elongation Percentage (EP), Welded Area Percentage (WAP), and Vickers Hardness (VH)

Mean and standard deviation values for UTS (MPa), WAP (\%) and EP (\%) in each tested group, without the control group, are shown in Table 1 and mean and standard deviation values for UTS (MPa) and EP (\%) in each tested group with the 
control group are shown in Table 2. The 1-way ANOVA showed significant differences among the groups for UTS, WAP and EP values $(P<.001)$.

Table 1. Means \pm standard deviations (SD) for ultimate tensile strength (MPa), welded area (\%), and elongation (\%), and statistical categories defined by Tukey test.

\begin{tabular}{llll}
\hline Diameter & $\begin{array}{l}\text { Ultimate Tensile Strength }(\mathbf{M P a}) \\
\text { Mean } \pm \text { SD }\end{array}$ & $\begin{array}{l}\text { Welded Area Percentage }(\%) \\
\text { Mean } \pm \text { SD }\end{array}$ & $\begin{array}{l}\text { Elongation Percentage }(\%) \\
\text { Mean } \pm \text { SD }\end{array}$ \\
\hline 2.5 & $990.72 \pm 130.47^{\mathrm{A}}$ & $87.65 \pm 16.36^{\mathrm{A}}$ & $1.39 \pm .75^{\mathrm{A}}$ \\
3.0 & $640.77 \pm 86.97^{\mathrm{B}}$ & $49.22 \pm 5.96^{\mathrm{B}}$ & $.35 \pm .09^{\mathrm{B}}$ \\
4.0 & $400.98 \pm 75.52^{\mathrm{C}}$ & $37.67 \pm 8.91^{\mathrm{BC}}$ & $.32 \pm .16^{\mathrm{B}}$ \\
5.0 & $381.20 \pm 78.43^{\mathrm{C}}$ & $36.27 \pm 8.68^{\mathrm{C}}$ & $.39 \pm .27^{\mathrm{B}}$ \\
\hline
\end{tabular}

Source: Authors.

Table 2. Mean fracture resistance values $(\mathrm{N})$ and standard deviations (SD), ultimate tensile strength (MPa) and elongation values (\%) of control and experimental groups ( $\mathrm{n}=5$ ), and $P$ values calculated by Dunnett test

\begin{tabular}{lllll}
\hline Group & Ultimate Tensile Strength (MPa) & $\boldsymbol{P}$ & Elongation Percentage $(\%)$ & $\boldsymbol{P}$ \\
\hline CG & $1008.5 \pm 37.1^{\mathrm{a}}$ & - & $7.5 \pm 1.2^{\mathrm{a}}$ & - \\
TIG2.5 & $990.72 \pm 130.47^{\mathrm{a}}$ & $=.984$ & $1.39 \pm .75^{\mathrm{b}}$ & $<.001$ \\
TIG3.0 & $640.77 \pm 86.97^{\mathrm{b}}$ & $<.001$ & $.35 \pm .09^{\mathrm{b}}$ & $<.001$ \\
TIG4.0 & $400.98 \pm 75.52^{\mathrm{b}}$ & $<.001$ & $.32 \pm .16^{\mathrm{b}}$ & $<.001$ \\
TIG5.0 & $381.20 \pm 78.43^{\mathrm{b}}$ & $<.001$ & $.39 \pm .27^{\mathrm{b}}$ & $<.001$ \\
\hline
\end{tabular}

Source: Authors.

For the UTS, the Dunnett test showed that the tested groups TIG3, TIG4, and TIG5 had UTS values lower than those of the control group, but the tested group TIG2.5 was not statistically significantly different in relation to control (Table 2). The Tukey test showed that the UTS values of the specimens with $2.5 \mathrm{~mm}$ diameter were significantly higher than those of the specimens with $3.0 \mathrm{~mm}, \quad 4.0 \mathrm{~mm}$, and $5.0 \mathrm{~mm}$ diameters, the UTS values of the specimens with $3.0 \mathrm{~mm}$ diameter were significantly higher than those of the specimens with $4.0 \mathrm{~mm}$ and $5.0 \mathrm{~mm}$ diameters, and the UTS values of the specimens with 4.0 and $5.0 \mathrm{~mm}$ diameter were not significantly different (Table 1).

For the WAP, the values of the specimens with $2.5 \mathrm{~mm}$ diameter were significantly higher than those of specimens with 3.0, 4.0, and $5.0 \mathrm{~mm}$ diameters, the values for specimens with $3.0 \mathrm{~mm}$ diameter were also significantly higher than those of specimens with $5.0 \mathrm{~mm}$ diameter but not significantly different from those of specimens with $4.0 \mathrm{~mm}$ diameter, and the specimens with 4.0 and $5.0 \mathrm{~mm}$ diameters were not significantly different (Table 1). Pearson correlation tests showed a positive (.913) correlation between UTS and WAP.

For EP values, the Dunnett test showed that all tested groups had lower EP values than the control group (Table 2). The Tukey test showed that the EP values of the specimens with $2.5 \mathrm{~mm}$ diameter were significantly higher than those of specimens with 3.0, 4.0, and $5.0 \mathrm{~mm}$ diameter (Table 1)

Mean and standard deviation values for Vickers hardness in each area are shown in Table 3. The 1-way ANOVA showed significant differences among the regions $(P<.001)$. 
Table 3. Means \pm standard deviations (SD) for Vickers hardness.

\begin{tabular}{lcc}
\hline Region & $\begin{array}{c}\text { Vickers Hardness (MPa) } \\
\text { Mean } \pm \text { SD }\end{array}$ & $\boldsymbol{P}$ \\
\hline Base Metal (BM) & $334.29 \pm 8.79^{\mathrm{A}}$ & $<.001$ \\
HAZ & $365.14 \pm 7.82^{\mathrm{B}}$ & $<.001$ \\
Welded Zone (WZ) & $393.19 \pm 8.17^{\mathrm{C}}$ & $<.001$ \\
\hline
\end{tabular}

Source: Authors.

The Tukey test showed that the WZ values were significantly higher than those for HAZ and BM $(P<.001)$, and those for HAZ were higher than those for BM $(P<.001)$.

\section{Scanning Electron Microscopy (SEM)}

Figures 1 and 2 are SEM images (original magnification $\times 100$ and $\times 20$, respectively) of the fractured welded area of TIG3 specimens.

Figure 1. Scanning electron microscope images of specimen from the TIG3 group at $\times 100$ magnification.

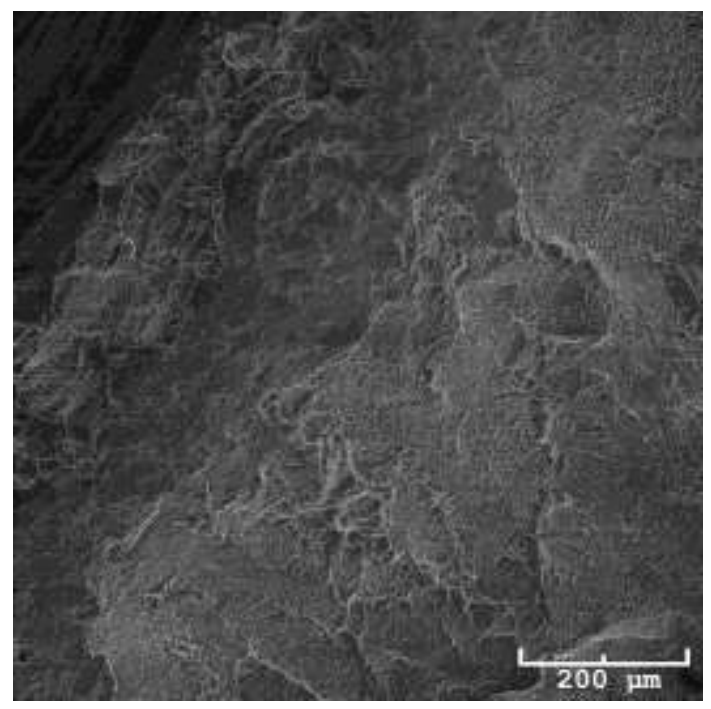

Source: Authors.

Figure 1. shows that the fracture in Ti-6Al-4V material after TIG welding presents a fairly flat overall surface with shallow dimples, indicating a small amount of ductility. 
Figure 2. Scanning electron microscope images of specimen from the TIG3 group at $\times 20$ magnification.

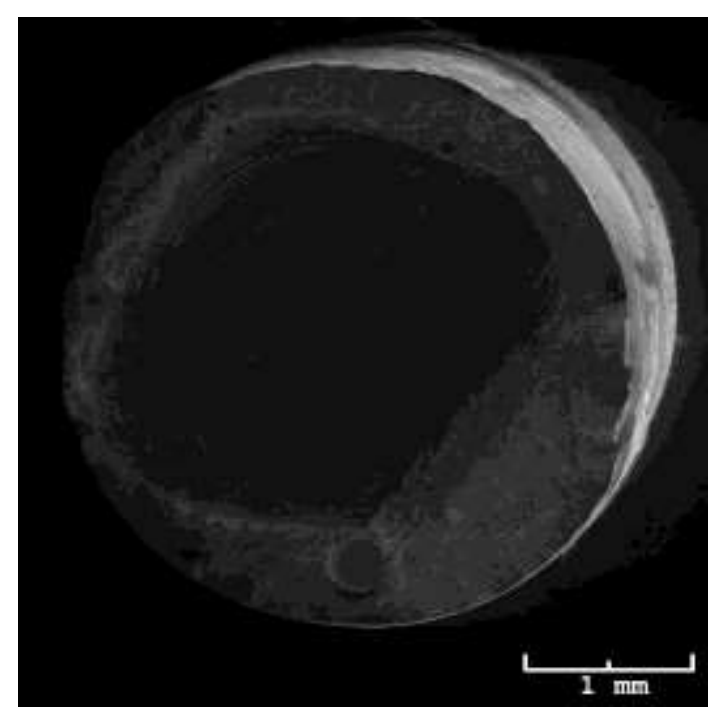

Source: Authors.

Figure 2 shows that a major portion of the central area was not joined and the presence of many voids and porosities in the welded area.

\section{Finite Element Analysis}

The values obtained from the FE models were compared with the values from the experimental models for directional deformation on the $\mathrm{X}$ axis, strain and stress for both intact and TIG-welded specimens for selected loads applied.

The stress x strain graph (Figure 3) shows that the curves for the experimental and FE model were very close. 
Research, Society and Development, v. 10, n. 9, e29110916481, 2021

(CC BY 4.0) | ISSN 2525-3409 | DOI: http://dx.doi.org/10.33448/rsd-v10i9.16481

Figure 3. Stress $\times$ strain curve of experimental and welded specimen numerical model.

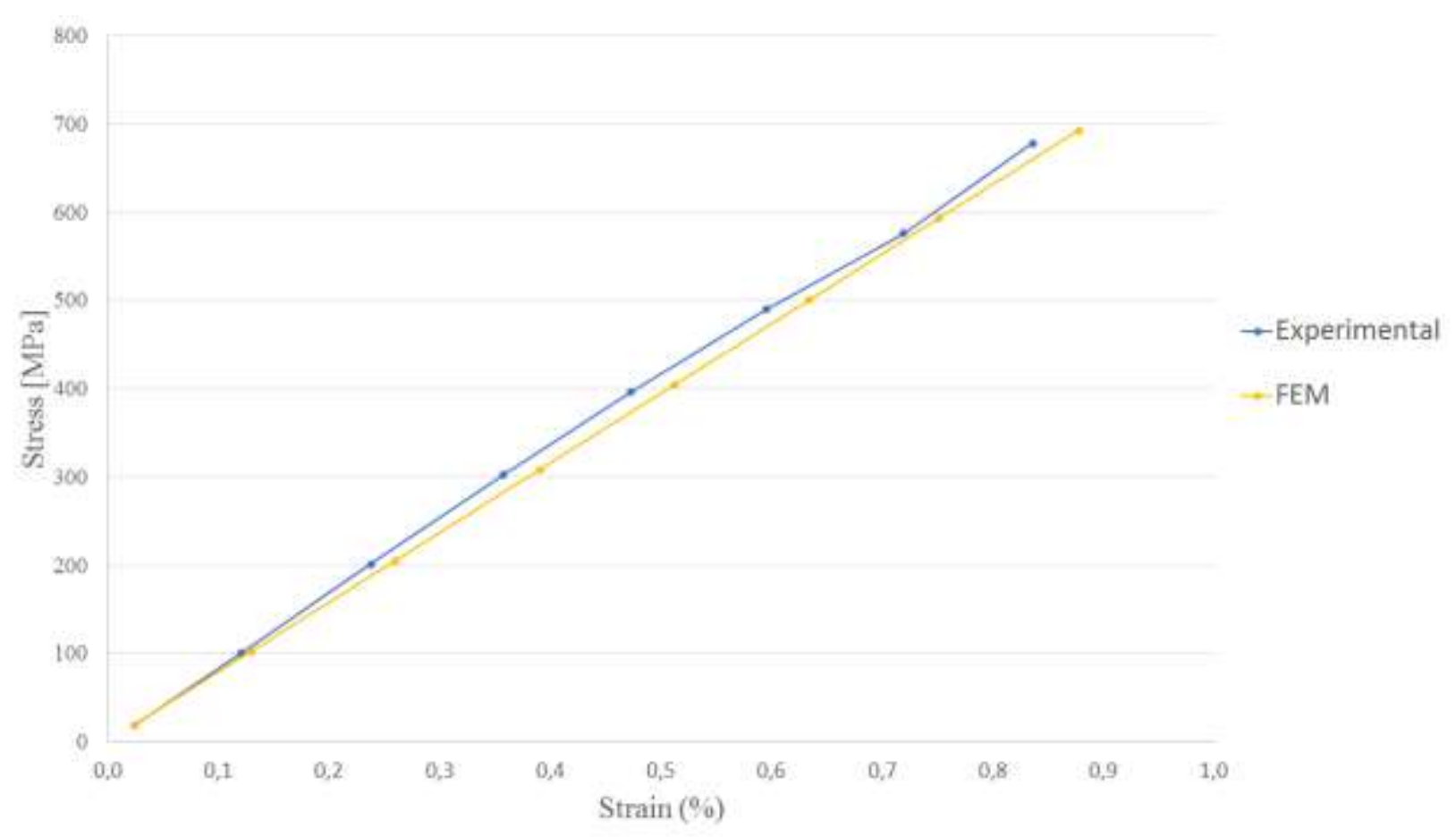

Source: Authors.

It could be seen that the stress concentration was throughout the central body of the intact specimen, meaning that fracture can occur at any point in this region; otherwise the welded sample has a higher concentration of stresses in the welded joint (Figure 4 and 5), mainly in the nonwelded region (Figure 6).

Figure 4. Model showing stress distribution throughout welded metal.
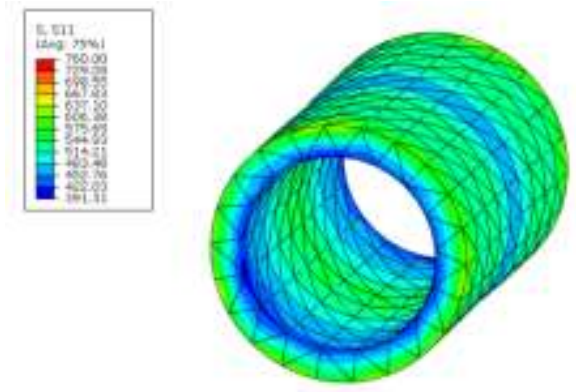

Source: Authors. 
Figure 5. Model showing stress distribution throughout HAZ zone.

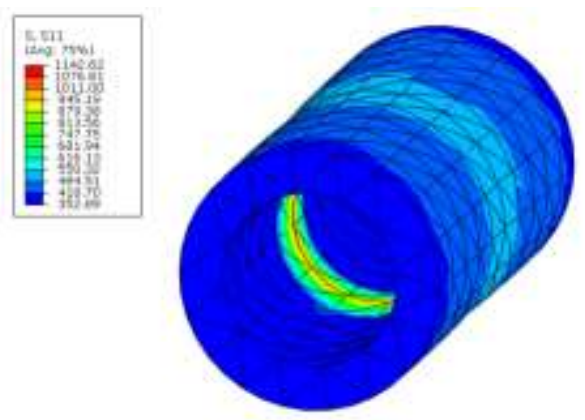

Source: Authors.

Figure 6. Model showing stress distribution throughout nonwelded metal with an internal void.

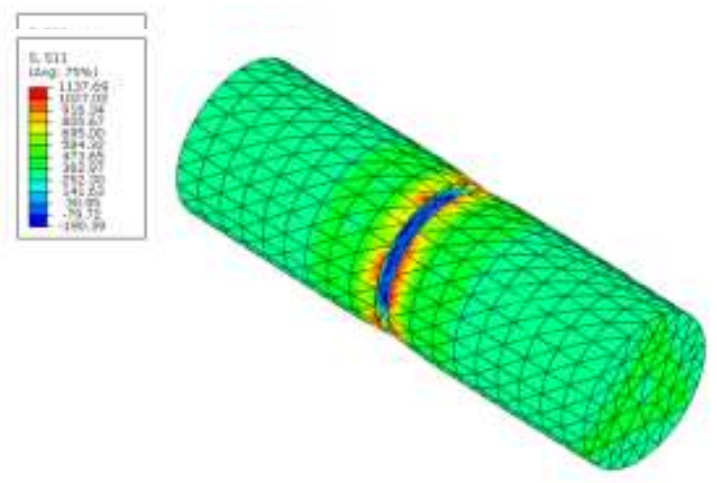

Source: Authors.

\section{Discussion}

The first hypothesis of this study was rejected. The 1-way ANOVA showed significant differences among the groups for UTS values and for EP values $(P<.001)$. For UTS, the Dunnett test showed that the tested groups TIG3, TIG4, and TIG5 had values lower than those of the control group, but tested group TIG2.5 had no statistically significant difference in relation to control. For EP, the Dunnett test showed that all tested groups had values lower than those of the control group.

Under suitable welding conditions, the resistance of welded joints should correspond to the resistance of specimens not welded (Berg, et al. 1995; Chai \& Chou, 1998; Taylor, et al. 1998; Byrne, 2011; Castro, et al. 2015).Thus, fracture can occur in any region of the cross-section of the sample (Berg, et al. 1995; Chai \& Chou, 1998; Rocha, et al. 2006; Castro, et al. 2015) and not necessarily in the welded region.

This behavior was identified only in the TIG2.5 group, where six of the 10 samples fractured in the base metal and not in the welded joint. In the other groups, all fractures occurred in the welded joint showing characteristics compatible with a ductile fracture on SEM images and the fractured samples in the welded area showed brittle fracture characteristics in some areas and ductile fracture in others, in addition to having a large internal void (Figures 1 and 2), confining the weld to only the periphery of the sample (Taylor, et al. 1998; Lyra e Silva, et al. 2012; Silveira-Júnior, et al. 2012; Takayama, et al. 2013; Castro, et al. 2015; Simamoto-Júnior, et al. 2015). This characterization of the fractures in welded samples also explains why the 
elongation values were lower for them than for intact samples, since welding reduces the ductility of titanium (Berg, et al. 1995; Castro, et al. 2015). Thus, the second hypothesis of this work was also rejected. The Tukey test showed that the values of the 2.5-mm-diameter specimen were significantly higher than those for specimens with 3.0-, 4.0-, 5.0-mm diameter for all parameters analyzed (UTS, WAP, and EP).

The occurrence of a large internal void caused by incomplete penetration could be one of the most significant factors for joint weakening (Berg, et al. 1995; Wang \& Welsch, 1995; Chai \& Chou, 1998; Nuñez-Pantoja, et al. 2011; Nuñez-Pantoja, et al. 2012; Atoui, et al. 2013; Lyra \& Silva, et al. 2012; Silveira-Júnior, et al. 2012; Takayama, et al. 2013; Castro, et al. 2015; Kokolis, et al. 2015; Simamoto-Júnior, et al. 2015; Silverio, et al. 2021). Several factors may contribute to this incomplete penetration, such as: changes in mechanical, physical, and chemical properties of metal resulting from the cooling and solidification of the metal after welding (Atoui, et al. 2013; Castro, et al. 2015); the regulation of the welding machine parameters (Chai \& Chou, 1998; Baba \& Watanabe, 2005; Watanabe \& Topham, 2006; Akman, et al. 2009; Lyra e Silva, et al 2012; NuñezPantoja, et al. 2012); and the configuration of the joints (Simamoto-Júnior, et al. 2015; Lyra e Silva, et al 2012; Takayama, et al. 2012; Kokolis, et al. 2015, Silverio, et al. 2021).

Among the parameters that can be adjusted are: peak power (current density or electrical voltage) (Chai \& Chou, 1998; Baba \& Watanabe, 2005; Akman, et al. 2009), pulse duration (Chai \& Chou, 1998; Rocha, et al. 2006; Akman, et al. 2009; Lyra e Silva, et al. 2012; Silverio, et al. 2021), and the diameter of the spot weld (Baba \& Watanabe, 2005; Akman, et al. 2009). Among these factors, variations in peak power appear to be the factor that most influences weld penetration (Chai \& Chou, 1998). In this work, the same current of $60 \AA$ and the same pulse of $120 \mathrm{~ms}$ were used, especially in the large-diameter samples with incomplete penetration, confirmed by 1-way ANOVA, which showed significant differences among the groups for WAP values $(P<.001)$.

In relation to joint configuration, some authors have claimed that I-shaped joints confine the welder only to the periphery of the sample, thereby generating a large internal void (Silveira-Júnior, et al. 2012; Castro, et al. 2015; Simamoto-Júnior, et al. 2015; Nuñez-Pantoja, et al. 2012; Takayama, et al. 2013; Silverio, et al. 2021). In all samples of the TIG3, TIG4, and TIG5 groups, the weld was confined to the periphery of the sample because of the joint configuration (Figure 2). Other joint configurations could be used, such as the X-shape, which favors greater weld penetration (Nuñez-Pantoja, et al. 2012; SimamotoJúnior, et al. 2015). Simamoto-Júnior et al. 2015 proposed the use of welded joints in the X-shape, and the mechanical behavior of the welded joints was greatly improved. TIG welding associated with the X-shaped design resulted in higher joint resistance, similar to that of the control group.

Moreover, in the SEM image, it was possible to detect bubbles or porosities inside the weld (Figure 2). It is possible that the porosities and internal voids are a result of the inclusion of the shielding gas (argon or helium) used in the TIG welding technique and necessary to maintain an inert atmosphere during the welding procedure and minimize interaction with the oxygen, hydrogen and nitrogen from the air (Akman, et al. 2009; Nuñez-Pantoja, 2011; Nuñez-Pantoja, 2012; Silveira-Júnior, et al. 2012; Castro, et al. 2015; Simamoto-Júnior, et al. 2015).

Internal voids in the form of bubbles act as both initiators and shortcomings of fracture, since they concentrate stress and can lead to the failure of welded structures in a short period of time under the application of stresses below those that an appropriately welded joint can bear (Nuñez-Pantoja, 2012; Silveira-Júnior, et al. 2012; Castro, et al. 2015; Simamoto-Júnior, et al. 2015; Silverio, et al. 2021).The finite element models showed that there was a higher concentration of stresses in the welded joints (Figures 4 and 5), most likely because of internal voids (Figure 6).

Two other factors could have influenced these results: the ability of the welder and the sharpening of the tungsten electrode. Some authors (Takayama, et al. 2012; Castro, et al. 2013; Kokolis, et al. 2015) allege that different welders and welder experience can also influence weld quality, but in this present work a single experienced welder welded all samples at one sitting, 
and therefore it is possible that the effects of this variable were minimized. Regarding sharpening, if a good-quality welded joint can be achieved, the non-consumable tungsten electrode requires sharpening in accordance with the specifications of the equipment manufacturer for each new spot weld (Silveira-Júnior, et al. 2012; Castro, et al. 2015; Simamoto-Júnior, et al. 2015). Since that was achieved in this work, it is likely that this variable had no influence on the results.

Finally, the third hypothesis of this work was accepted. The 1-way ANOVA showed significant differences among the regions $(P<.001)$. The Tukey test showed that values for the $\mathrm{WZ}$ were significantly higher than those for the HAZ and BM $(P<.001)$, and that those for HAZ were higher than those for BM $(P<.001)$. These differences among regions are a result of microstructural changes of the material after being welded (Wang \& Welsch, 1995; Akman, et al. 2009). However, resistance, in this case, depended primarily on the flaws (bubbles and internal porosities) more than on the metal properties in WZ (Berg, et al. 1995).

Although the Ti-6Al-4V alloy was used in this work because of its favorable chemical, mechanical, and biological properties, other alloys can be used for evaluation and compared with the results obtained in this work.

\section{Conclusions}

Within the limitations of this research, the diameters of 2.5 and $3.0 \mathrm{~mm}$ showed the highest values of UTS and WAP and seem to be the best option for joining prefabricated bars for use in prosthetic frameworks for TIG welding, in terms of machine regulation and configuration of the joints used in this study. Suggestions for future studies include fatigue tests, microCT evaluation, metallographic, and residual contraction evaluation.

\section{Acknowledgment}

The authors would like to thank the support of FAPEMIG. The project was supported by FAPEMIG (2012-SAU030)

\section{References}

ASTM. (2008). Designation: E 8M - 04, Standard Test Methods for Tension Testing of Metallic Materials. American Society for Testing and Materials International (ASTM) International, West Conshohocken, PA, 24 p. https://www.astm.org/Standards/E8M

ASTM. (2003). Designation: ASTM E92, Standard Test Methods for Vickers Hardness and Knoop Hardness of Metallic Materials, (ASTM) International, West Conshohocken, PA. https://www.astm.org/Standards/E92

Atoui, J. A., Felipucci, D. N. B., Pagnano, V. O., Orsi, I. A., Nóbilo, M. A. A., \& Bezzon, O. L. (2013). Tensile and flexural strength of commercially pure titanium submitted to laser and tugsten inert gas welds. Brazilian Dental Journal, 24(6):630-634. https://doi.org/10.1590/0103-6440201302241

Akman, E., Demir, A., Canel, T., \& Sinmazçelik, T. (2009). Laser welding of Ti6Al4V titanium alloy. Journal of Materials Processing Technology, 209(8):37053713. https://doi.org/10.1016/j.jmatprotec.2008.08.026

Baba N., \& Watanabe, I. (2005). Penetration deph into dental casting alloys by Nd:YAG laser. Journal of Biomedical Materials Research Part B: Applied Biomaterials, 72B(1):64-68. https://doi.org/10.1002/jbm.b.30117

Barbi, F. C. L., Camarini, E. T., Silva, R. S., Endo, E. H., \& Pereira, J. R. (2012). Comparative analysis of different joining techniques to improve the passive fit of cobalt-chromium superstructures. The Journal of Prosthetic Dentistry, 108(6):377-385. https://doi.org/10.1016/S0022-3913(12)60196-6

Berg, E., Wagner, W. C., Davik, G., \& Dootz, E. R. (1995). Mechanical properties of laser-welded cast and wrought titanium. The Journal of Prosthetic Dentistry, 74 (3):250-257. https://doi.org/10.1016/S0022-3913(05)80131-3

Byrne, G. (2011). Soldering in prosthodontics - an overview, part I. Journal of Prosthodontics, 20(3):233-243. https://doi.org/10.1111/j.1532849X.2011.00691.x

Castro, G. C., Araújo, C. A., Mesquita, M. F., Consani, R. L. X., \& Nóbilo, M. A. A. (2013).Stress distribution in Co-Cr implant frameworks after laser or TIG welding. Brazilian Dental Journal, 4(2):147-151. https://doi.org/10.1590/0103-6440201302112

Castro, M. G., Araújo, C. A., Menegaz, G. L., Lyra e Silva, J. P., Nóbilo, M. A. A., \& Simamoto-Júnior, P. C. (2015). Laser and Plasma dental soldering techniques applied to Ti-6Al-4V alloy: Ultimate tensile strength and finite elemento analysis.The Journal of Prosthetic Dentistry, 113(5):460-466. https://doi.org/10.1016/j.prosdent.2014.10.008 
Chai, T., \& Chou, C. K. (1998). Mechanical properties of laser-welded cast titanium joints under different conditions. The Journal of Prosthetic Dentistry, 79(4):477-483. https://doi.org/10.1016/S0022-3913(98)70165-9

Kokolis, J., Chakmakchi, M., Theocharopoulos, A., Prombonas, A., \& Zinelis, S. (2015). Mechanical and interfacial characterization of laser welded Co-Cr alloy with diferente joint configurations. The Journal of Advanced Prosthodontics, 7(1):39-46.https://doi.org/10.4047/jap.2015.7.1.39

Lyra e Silva, J. P., Fernandes Neto, A. J., Raposo, L. H. A., Novais, V. R., Araujo, C. A., Cavalcante, L. A. L., \& Simamoto-Júnior, P. C. (2012).Effect of plasma welding parameters on the flexural strength of Ti-6Al-4V alloy. Brazilian Dental Journal, 23(6):686-691. https://doi.org/10.1590/S010364402012000600010

Nuñez-Pantoja, J. M. C., Takahashi, J. M. F. K., Nóbilo, M. A. A., Consani, R. L. X., \& Mesquita, M. F. (2011). Radiographic inspection of porosity in Ti-6Al4V laser-welded joints. Brazilian Oral Research, 25(2):103-108. https://doi.org/10.1590/S1806-83242011005000005

Nuñez-Pantoja, J. M. C., Farina, A. P., Vaz, L. G., Consani, R. L. X., Nóbilo, M. A. A., \& Mesquita, M. F. (2012). Fatigue strength: effect of welding type and joint design executed in Ti-6Al-4V structures. Gerodontology, 29(2):e1005-e1010. https://doi.org/10.1111/j.1741-2358.2011.00598.X

Perveen, A., Molardi, C., \& Fornaini, C. (2018). Applications of Laser Welding in Dentistry: A State-of-the-Art Review. Micromachines, 9(5): 209. https://doi.org/10.3390/mi9050209

Rocha, R., Pinheiro, A. L. B., \& Villaverde, A. B. (2006). Flexural strength of pure Ti, Ni-Cr and Co-Cr alloys submitted to Nd:YAG laser or TIG welding. Brazilian Dental Journal, 17(1):20-23. http://dx.doi.org/10.1590/S0103-64402006000100005

Silveira-Júnior, C. D., Castro, M. G., Davi, L. R., Neves, F. D., Novais, V. R., \& Simamoto-Júnior, P. C. (2012). Welding techniques in dentistry. In: Kovacevic R (Ed.), Welding Processes. $17^{\text {th }}$ ed (pp. 415-438). Croatia: In tech.

Simamoto-Júnior, P. C., Novais, V. R., Machado, A. R., Soares, C. J., \& Raposo, L. H. A. (2015).Effect of joint design and welding type on the flexural strength and wel penetration of Ti-6Al-4V alloy bars. The Journal of Prosthetic Dentistry, 113(5):467-474.https://doi.org/10.1016/j.prosdent.2014.10.010

Takayama, Y., Nomoto, R., Nakajima, H., \& Ohkubo, C. (2012). Effects of argon flow rate on laser-welding. Dental Materials Journal, 31(2):316-326. https://doi.org/10.4012/dmj.2011-158

Takayama, Y., Nomoto, R., Nakajima, H., \& Ohkubo, C. (2013) Comparasion of joint designs for laser welding of cast metal plates and wrought wires. Odontology, 101:34-42. https://doi.org/10.1007/s10266-011-0049-7

Taylor, J. C., Hondrum, S. O., Prasad A., \& Brodersen C. A. (1998). Effects of joint configuration for the arc welding of cast Ti-6Al-4V alloy rods in argon.The Journal of Prosthetic Dentistry, 79(3):291-297. https://doi.org/10.1016/S0022-3913(98)70240-9

Wang, R. R., \& Welsch, G. E. (1995). Joining titanium materials with tungsten inert gas welding, laser welding, and infrared brazing. The Journal of Prosthetic Dentistry, 74(5):521-530. https://doi.org/10.1016/S0022-3913(05)80356-7

Watanabe, I., \& Topham, D. S. (2006). Laser welding of cast titanium and dental alloys using argon shielding. Journal of Prosthodontics, 15(2):102-107. https://doi.org/10.1111/j.1532-849X.2006.00082.x

Welsch, G., Boyer, R., \& Collings, E. W. (1993). Materials Properties Handbook: Titanium alloys materials properties handbook. In ASM International (Ed.), 1176 p. 